DOI: https://doi.org/10.31933/dijemss.v2i1

Received: 25 August 2020, Revised: 18 October 2020, Publish: 29 November 2020

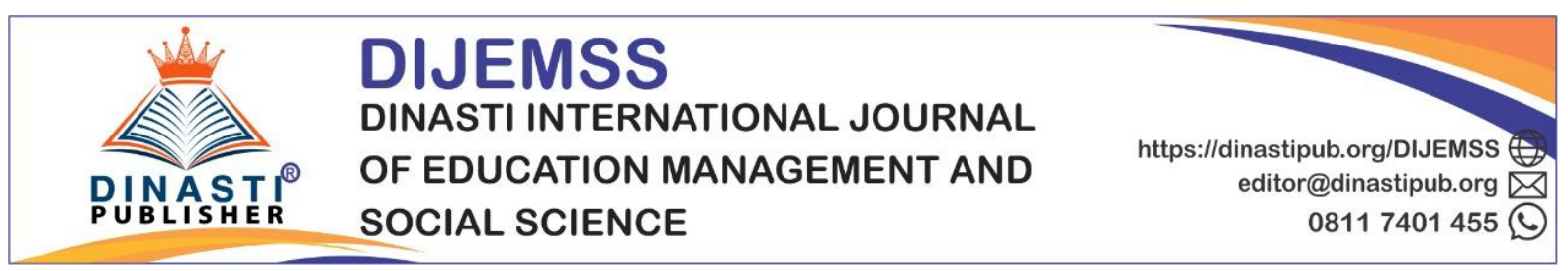

\title{
EMPLOYEE PERFORMANCE MODELS: COMPETENCE, COMPENSATION AND MOTIVATION (HUMAN RESOURCES LITERATURE REVIEW STUDY)
}

\author{
Muhammad Reza Putra ${ }^{1}$, Gupron ${ }^{2}$ \\ ${ }^{1)}$ Ph.D Student, Universiti Kebangsaan Malaysia, muhammad_reza@upiyptk.ac.id \\ ${ }^{2)}$ Lecturer of Universitas Batanghari Jambi, gupron@unbari.ac.id
}

\section{Corresponding author: ${ }^{2)}$ Gupron}

\begin{abstract}
In a company, employees are one of the most important elements in achieving company goals. The performance of an employee is certainly influenced by several factors that a manager needs to know. Managers must know the strengths and weaknesses of each manager in order to maximize potential and minimize employee shortages. The factors that influence an employee's performance are motivation, compensation and competence. Motivation is needed by an individual because basically humans need encouragement or inducement in order to work better. Motivation is given as a way to improve employee performance to carry out their responsibilities. The different competencies of each employee are also a factor in the good and bad performance of an employee. The competence of each employee must be improved in order to achieve company goals. Compensation also affects an employee's performance. Compensation can be in the form of money or other facilities. Compensation is given as remuneration by the company to employees who have carried out their duties and responsibilities.
\end{abstract}

Keywords: Employee performance, competence, compensation, motivation

\section{INTRODUCTION}

The performance of a company is determined by the performance of all its employees. In this case, the manager or director of a company must know how well their employees are performing at work. Therefore, a research or research is needed in order to find out what actors influence employee performance, for example, namely, motivation, competence and compensation.

An employee is the most important component in a company to carry out the production to distribution process. At work, employees really need encouragement and motivation from a manager or other employees. Working together by giving each other 
enthusiasm and motivation in achieving company goals is very necessary because by working together work will be more effective and efficient. Motivation is an encouragement, a lure, or an incentive that a person needs to do better. Motivation to employees is one of the factors that must always be done by a manager along with other managerial factors. Apart from being a leader, a manager must also be a friend as well as a motivator for every employee.

Employee performance can be a measure of how human resources in a company have played a role in the progress of the company or not. To achieve the best goals in a company, of course, clear human resource management is needed through various company policies that can adjust the mutual interests of the company and employees. However, employee performance will be better if there is self-awareness and sincerity of each employee as an individual in carrying out their duties and responsibilities.

Performance is the work result in quality and quantity achieved by an employee in carrying out his duties in accordance with the responsibilities assigned to him (Mangkunegara, 2009). One of the factors that can grow employee performance is the potential within the employee itself in the form of competencies that are continuously developed and adapted to their needs at work.

\section{Formulation of the problem}

Based on the above background, this article will discuss the formulation of the problem as follows:

1) Does competency have a relationship and affect employee performance

2) Does compensation have a relationship and influence on employee performance

3) Does motivation have a relationship and affect employee performance

\section{LITERATURE REVIEW}

\section{Employee performance}

Performance is a function of motivation and the ability to complete a task or someone's job should have a certain degree of willingness and level of ability. A person's willingness and skills are not effective enough to do something without a clear understanding of what to do and how to do it. Performance is a tangible behavior that is displayed by each person as a work achievement produced by employees in accordance with their role in the organization. Employee performance is very important in the organization's efforts to achieve goals (Rivai and Sagala, 2009).

The term performance comes from the word job performance or actual performance (work performance or actual achievement achieved by a person), namely the quality and quantity of work achieved by an employee in carrying out his duties in accordance with the responsibilities assigned to him (Mangkunegara, 2011). This definition provides an understanding that performance is an act or behavior of a person in carrying out his duties, which can be observed and assessed by others.

From several theories regarding performance, it can be concluded that performance is a result of work or the level of success achieved by workers in their field of work which can be directly reflected in the output produced in terms of both quantity and quality, according to 
the criteria applied to the job. Which can be measured through 1) technical ability; 2) Conceptual skills; 3) Responsibility; 4) Initiatives; and 5) Interpersonal relationship skills.

The performance has been researched by many previous researchers, including: (Ali et al., 2016), (Prihartono \& Ali, 2020), (Ansori \& Ali, 2017), (Harini et al., 2020), (Riyanto, Pratomo, et al., 2017), (Brata, Husani, Hapzi, 2017), (Agussalim, Kristin, et al., 2016), (Agussalim, Kristin, et al., 2016), (Ali et al., 2016), (Desfiandi et al., 2017), (Sulaeman et al., 2019), (Ansori \& Ali, 2017), (Djojo \& Ali, 2012), (Riyanto, Sutrisno, et al., 2017a), (Prayetno \& Ali, 2017), (Ridwan et al., 2020), (Djoko Setyo Widodo, P. Eddy Sanusi Silitonga, 2017), dan (Agussalim, Ayu Rezkiana Putri, et al., 2016).

\section{Competence}

Competence is a basic character of a person who has an indication of how to behave or think in a wide range of situations and last for a long time. Competence can be said as basic behavior that describes the motives, personal characteristics, and knowledge or skills possessed by a person with high performance in the workplace.

The terms competencies, "competence", and "competent" which in Indonesian are translated as competence, proficiency and empowerment which refer to a state of capable and appropriate quality. The English dictionary defines the word "competence" as a state of being fit, adequate, or suitable. The definition of competence in the workplace refers to the understanding of a person's suitability for his job. However, in the context of work, the potential has two different meanings, based on how the company is structured.

The competence of each employee is one of the important assets for a company. Employees who have good competency potential will have a positive impact in the production process because they have good performance. Every employee has different competencies, so the manager's job is to supervise and continuously improve the competence of each employee based on their competencies. Wibowo (2007: 324) states that competence is the ability to carry out or do a job that is based on skills and knowledge and is supported by the work attitude demanded by the job.

competence has a positive and significant effect directly on employee performance (Siwantara, 2012). This is supported by research from Sulistyaningsih (2009) which also shows that competence has a positive effect on employee performance.

Motivation is a process that describes the intensity, direction, and persistence of an individual to achieve company goals. Work motivation is an important part of a company that functions as a tool to achieve goals or objectives to be achieved (Robbins, 2008). In addition, in work motivation there are two main goals in individuals, namely to meet personal needs or desires and company goals. Therefore, the work motivation given to each employee will only be effective and work if there is a belief in a person to progress and continue to develop in the company.

Each employee has different self-competencies and can certainly be relied on in achieving company goals. Competence is one of the important assets for employees to work actively and professionally. Of course, this competence must be continuously improved so 
that in the future employees can contribute better to the company. This competence is one of the important assets for every employee to contribute professionally and totality so as to increase company productivity.

Competence is a characteristic that becomes the basis for a person at work or the basic characteristics of an individual who has a cause-and-effect relationship with the criteria used as a reference, effective, superior, or works best in the workplace or in certain situations (Moeheriono, 2012). Competence is the basis for an employee in doing his job in accordance with the demands of the job for which he is responsible. Thus, employees need to continue to adapt in order to develop so that they meet competency standards in accordance with their respective fields.

The competencies that have been researched by many previous researchers include: (Ansori \& Ali, 2017), dan (Ridwan et al., 2020).

\section{Compensation}

Compensation is everything that is received, either physical or non-physical. Compensation also means all benefits received by a worker / employee for services or results from his work in a company in the form of money or goods, either directly or indirectly. This term is very closely related to financial rewards given to someone on the basis of a work relationship.

The existence of compensation provided by the company to employees certainly has a positive impact that can provide benefits, both for the company and employees. Well, here are the positive impacts a company or organization can get:

a) Encourage employees to always excel and work hard.

b) Can be an attraction also for quality job seekers.

c) The company image books looks better than competitors.

d) Companies can find quality workers.

e) Facilite existing administrative processes and legal aspects.

Compensation or salary according to experts is all forms of remuneration from the company for the performance provided by employees. This remuneration can be in the form of money or other facilities provided by the company to employees for the work they have done. The amount of compensation is usually determined by the employee and the previous company at the beginning of the work contract so that the employee will know how much compensation he gets. The amount of compensation can be different depending on the position and performance of each employee. In general, compensation can be divided into two, namely:

1) Direct compensation. Direct compensation is compensation that can be felt directly by employees, in the form of basic salary, allowances, incentives which are the right of employees and it is the company's obligation to provide such compensation.

a. Salary is remunation that is paid periodically to permanent employees and has a definite guarantee. 
b. Allowances are compensation provided by the company to its employees which are considered to have participated well in achieving the company's goals.

c. Incentives are compensation given to certain employees because their success is above the standard.

2) Indirect compensation. According to Sofyandi (2008), indirect compensation is compensation given to employees as a company effort to improve employee welfare. This compensation is provided outside of salary, allowances, and incentives. Indirect compensation can be in the form of facilities provided by the company for its employees, such as housing, free medical services, etc.

Compensation is also a factor for employees to improve their performance. The amount of compensation will affect employee performance so that the company must communicate with employees to determine the amount of compensation that will be obtained so that employees work professionally. The success in determining the appropriate compensation for employees will determine how the quality of human resources will work, which will be related to the effectiveness and efficiency of the company. In addition, proper compensation will also determine the sustainability of a company in an increasingly competitive business environment. That way, appropriate and appropriate compensation will affect the performance displayed by employees. When compensation is not in accordance with employee expectations, rejection will occur until an employee demonstration can occur.

The compensation has been widely studied by previous researchers, including: (Riyanto, Pratomo, et al., 2017), dan (Purba et al., 2017).

\section{Compensation Purpose of the Company for Employees}

In addition to the positive impacts a company can get, of course the company also has a goal of providing compensation to its employees. The following are some of the objectives of compensation from the company for its employees:

a) Retaining Existing Outstanding Employees. The first goal is to retain employees who are considered potential and qualified to continue working. It is also useful for preventing high employee turnover rates.

b) Getting Qualified Employees. One way for a company or organization to get qualified employees or prospective applicants is by providing a fairly competitive level of compensation compared to other companies / organizations.

c) Ensuring Justice in the Company. Another objective is to ensure fairness in the relationship between management and employees. It also aims to reward the organization for whatever has been done or served by an employee to the company. So, fairness in providing wages, bonuses, incentives, etc. in the company is absolutely considered by the company.

d) Efficient Cost. This one goal is intended, if a company plans or establishes a rational compensation program, it will help the company or organization obtain and maintain 
human resources at a reasonable cost level. With competitive wages, incentives, bonuses, etc., the company will get a balance from the increased work ethic of employees.

e) Meet the Legality Administration. In the administration of compensation that should exist in every company there are also legality limits regulated by the government in a law. So, this administration procurement in a company also aims to fulfill legality administration.

f) Trigger Behavior and Attitude Changes for the Better. The goal that the company expects from the existence of appropriate and fair compensation to employees is that employees can have good attitudes and behaviors that can benefit and affect work productivity. Good work, loyalty, experience, responsibility and other behaviors that can be increased thanks to being rewarded through the effective facilities of the company / organization.

Compensation can be referred to as an award or remuneration from the company to employees as remuneration for contributions made by employees to the company. For organizations / companies, compensation means rewards for employees who have contributed to realizing common goals, through activities called work (Nawawi, 2003). That way, employee satisfaction with the compensation obtained is when the employee's attitude is happy with the amount of compensation received, both in the form of money and other facilities as remuneration for tasks and responsibilities that have been completed.

Compensation can be given in different forms, such as salary, allowances, and other bonuses. Salary is a form of remuneration by the company to employees in the form of money in return for the contributions that employees have given to the company to achieve its goals (Kadarisman, 2012). The level of salary in a company is very important because it affects the company's ability to attract and retain employees who have competence and a competitive position in the product market.

Allowances are additional income provided by a company to its employees (Kaderisman, 2012). This allowance is given as a form of corporate social responsibility and service to its employees to provide a sense of security in their financial needs.

The bonus is incentive compensation. Bonuses will be obtained by employees who are able to work more so that new production levels can be exceeded (Kaderisman, 2012). Bonuses are given in the form of cash and given on the basis of the amount of profit or evaluation of individual or company work performance. Payment of bonuses and allowances is usually given in conjunction with salary payments in the same period. Salaries, allowances, and bonuses have a positive effect on employee performance.

\section{Motivation}

Performance is a factor in the achievement of a company goal. To complete tasks and jobs, someone should have high enthusiasm and a certain level of ability. One's readiness and skills are not effective enough to do something without a clear understanding of what to do and how to do it. Employee performance is very important in the company's efforts to achieve its goals. 
Motivation is a process that describes the intensity, direction and persistence of an individual to achieve his goals. The three main elements in this definition are intensity, direction and persistence. Based on Abraham Maslow's hierarchy of needs theory, Douglas McGregor's theory of $\mathrm{X}$ and $\mathrm{Y}$ theory as well as contemporary motivation theory, the meaning of motivation is the 'reason' that underlies an action performed by an individual. Someone is said to have high motivation, it can be interpreted that the person has very strong reasons to achieve what he wants by doing his current job seriously. This is different from motivation in the sense that develops in society which is often equated with 'enthusiasm', for example in the conversation "I want my child to be highly motivated". This statement can be interpreted that the parent wants their child to have a high enthusiasm for learning. So, it needs to be understood that there are differences in the use of the term motivation in society. There are those who interpret motivation as a reason, and there are also those who interpret motivation with enthusiasm.

Motivation comes from the Latin "movere", which means to move. According to Weiner (1990), motivation is defined as an internal condition that arouses us to act, encourages us to achieve certain goals, and keeps us interested in certain activities. According to Uno (2007), motivation can be interpreted as internal and external encouragement in a person which is indicated by the existence of desires and interests, drives and needs, hopes and ideals, appreciation, and respect. Meanwhile, Imron (1966) explains that motivation comes from the English word "motivation" which means encouragement or reasons to carry out an activity to achieve a goal.

According to Bernanard and Gary A. Stainer in Machrony defines motivation as all those inner striving conditions variously described as wishes, desires, needs, drives, and the like. Motivation can be defined as a mental state and mental attitude of a human being that provides energy encouragement in activities (moves) and leads or channels behavior toward achieving needs that provide personal or group satisfaction or reduce imbalances.

From the definitions that have been described above, motivation can be concluded as a condition that moves an individual towards a certain goal; an expertise in directing employees to be willing to work optimally so that their desires can be achieved properly; as an energy to generate impulses in oneself and as a condition of effect to arouse; directing and maintaining behavior related to the work environment.

Motivation encourages behavior that affects and changes the nature and behavior of the original. These functions are:

a) Encouraging behavior or an action, without motivation there will be no action or action.

b) Motivation functions as influence, which means directing action to achieve the desired goals.

c) Motivation serves as a driving forces. The size of the motivation will determine the speed or delay the job.

To improve employee performance and productivity, companies need to motivate employees. This is done so that employees can achieve high and can achieve company goals. Motivation is a series of positive attitudes or values that influence individuals to do 
something better and better. These positive attitudes and values make an individual strive to achieve the goals he wants to achieve. Indeed, motivation is owned by every human being in himself. Motivation is a unique sense of as well as past thoughts and experiences. Motivation is always needed so that employees can continue to improve their performance consistently.

Motivation comes from the Latin word movere which means to move. Motivation is the driving force that creates a person's morale so that they are willing to work with all their power and efforts to achieve individual satisfaction (Winardi, 200).

Motivation is a process that explains the intensity and direction of a human being's persistence to achieve life goals (Robbins, 2008). Based on this opinion it can be concluded that; (1) motivation is an urgent factor in a company that is useful as a tool in achieving the goals and objectives to be obtained; (2) Motivation has two main objectives, namely to fulfill personal needs and company goals; and (3) motivation will be effective if it is given to someone who has the confidence to continue to develop and become better in a company.

Managers as leaders in a company must be a motivator for their employees. managers / company leaders must play themselves as good supervisors for their employees, so that employees can work with high motivation and productivity (Ali, 2010).

Motivation is a process or action that can inspire employees to achieve goals. On the background of job objectives, there are several psychological factors that motivate employee behavior, including job satisfaction, achievement satisfaction, economic needs, and the value of respect / appreciation. Employees will be more productive if motivated than employees who are not motivated to work. Every employee has a different way of getting motivated so that managers need to know the nature and character of their employees in order to provide motivation for their employees. Motivation in a production process is useful as an encouragement in running and maintaining the existence of a company in order to survive.

The motivations that have been researched by previous researchers include: (Riyanto, Sutrisno, et al., 2017a), (Bastari et al., 2020), (Prayetno \& Ali, 2017), (Rivai et al., 2017), dan (Chauhan et al., 2019).

\section{RESEARCH METHODS}


The method of writing scientific articles is to use the library research method or literature review. Review literature books in accordance with the theory discussed, especially in the HRM environment. Besides, it analyzes reputable scientific articles as well as scientific articles from journals that are not yet reputable. All cited scientific articles are sourced from Mendeley and Google Scholar. Yudistira and Siwantara (2012) state that literature reviews are written summaries of articles from journals, books and other documents that describe theories and information, both past and present, organizing literature into topics and documents needed (Siwantara, 2012).

The type of data used by the author in this study is data obtained from library research. Library research is a method used to collect data or sources related to the topics raised in research. Then use the descriptive analysis method to analyze the data obtained. Descriptive analysis method is done by describing facts, then analyzing these facts, not only describing, but also providing adequate understanding and explanation.

\section{RESULTS AND DISCUSSION}

\section{The effect of competence on performance $\backslash$}

Competence and performance have been discussed by many previous researchers, including Wibowo (2007: 324) which states that competence is the ability to carry out or do a job that is based on skills and knowledge and is supported by the work attitude demanded by the job. Meanwhile, Yudistira and Siwantara (2012) state that competence has a positive and significant effect directly on employee performance. This is supported by research from Sulistyaningsih (2009) which also shows that competence has a positive effect on employee performance.

Performance is a factor in the achievement of a company goal. To complete tasks and jobs, someone should have high enthusiasm and a certain level of ability. One's readiness and skills are not effective enough to do something without a clear understanding of what to do and how to do it. Employee performance is very important in the company's efforts to achieve its goals.

From the explanation above, it can be concluded that employee competence and performance are two interrelated things. Where the more competencies of an employee, where the competence supports to work better, the better the employee's performance at work. So that you could say that competence and performance have a directly proportional relationship.

The relationship or influence of competence on employee performance is in line with the previous articles, including: Competence: (Ansori \& Ali, 2017), dan (Ridwan et al., 2020). Kinerja karyawan: (Riyanto, Sutrisno, et al., 2017a), (Prayetno \& Ali, 2017), (Ridwan et al., 2020), (Djoko Setyo Widodo, P. Eddy Sanusi Silitonga, 2017) dan (Agussalim, Ayu Rezkiana Putri, et al., 2016).

\section{Effect of Compensation on Performance}


Compensation and performance have been widely studied by previous researchers, including Nawawi (2003) who says that for organizations / companies, compensation means rewards for employees who have contributed to realizing common goals, through activities called work. Then there is Kadarisma (2003) which states that a salary is a form of remuneration by the company to employees in the form of money in return for the contributions that employees have given to the company to achieve its goals.

Performance is a factor in the achievement of a company goal. To complete tasks and jobs, someone should have high enthusiasm and a certain level of ability. One's readiness and skills are not effective enough to do something without a clear understanding of what to do and how to do it. Employee performance is very important in the company's efforts to achieve its goals.

From the explanation above, it can be concluded that employee compensation and performance are two interrelated things. Where the more compensation an employee receives, either directly or indirectly, the better the employee's performance at work. So that you could say that compensation and performance have a directly proportional relationship.

The relationship or effect of compensation on employee performance is in line with the previous articles, including: Compensation: (Riyanto, Pratomo, et al., 2017), and (Purba et al., 2017). Employee performance: (Riyanto, Sutrisno, et al., 2017a), (Prayetno \& Ali, 2017), (Ridwan et al., 2020), (Djoko Setyo Widodo, P. Eddy Sanusi Silitonga, 2017) dan (Agussalim, Ayu Rezkiana Putri, et al., 2016).

\section{The influence of Motivation on Employee Performance}

Motivation and performance have been widely studied by previous researchers, one of which is (Robbin, 2008), that; (1) motivation is an urgent factor in a company that is useful as a tool in achieving the goals and objectives to be obtained; (2) Motivation has two main objectives, namely to fulfill personal needs and company goals; and (3) motivation will be effective if it is given to someone who has the confidence to continue to develop and become better in a company.

Performance is a factor in the achievement of a company goal. To complete tasks and jobs, someone should have high enthusiasm and a certain level of ability. One's readiness and skills are not effective enough to do something without a clear understanding of what to do and how to do it. Employee performance is very important in the company's efforts to achieve its goals.

There is one researcher named (Winardi 2002), states that the term motivation comes from Latin, namely movere which means to move (to move). Motivation is the driving force that creates a person's morale so that they are willing to work with all their power and efforts to achieve individual satisfaction.

From the explanation above, it can be concluded that employee motivation and performance are two related things. Where the more motivation an employee has, be it motivation to work, earn money and / or support his family, the better the employee's 
performance at work. So that you could say that motivation and performance have a directly proportional relationship.

The relationship or influence of motivation on employee performance is in line with the previous articles including: Motivation: (Riyanto, Sutrisno, et al., 2017a), (Bastari et al., 2020), (Prayetno \& Ali, 2017), (Rivai et al., 2017), dan (Chauhan et al., 2019). Employee Performance: (Riyanto, Sutrisno, et al., 2017a), (Prayetno \& Ali, 2017), (Ridwan et al., 2020), (Djoko Setyo Widodo, P. Eddy Sanusi Silitonga, 2017) dan (Agussalim, Ayu Rezkiana Putri, et al., 2016).

\section{Conceptual Framework:}

Based on the theoretical study and the relationship between variables, the model or Conceptual Framework of this article in order to construct a hypothesis is as follows:

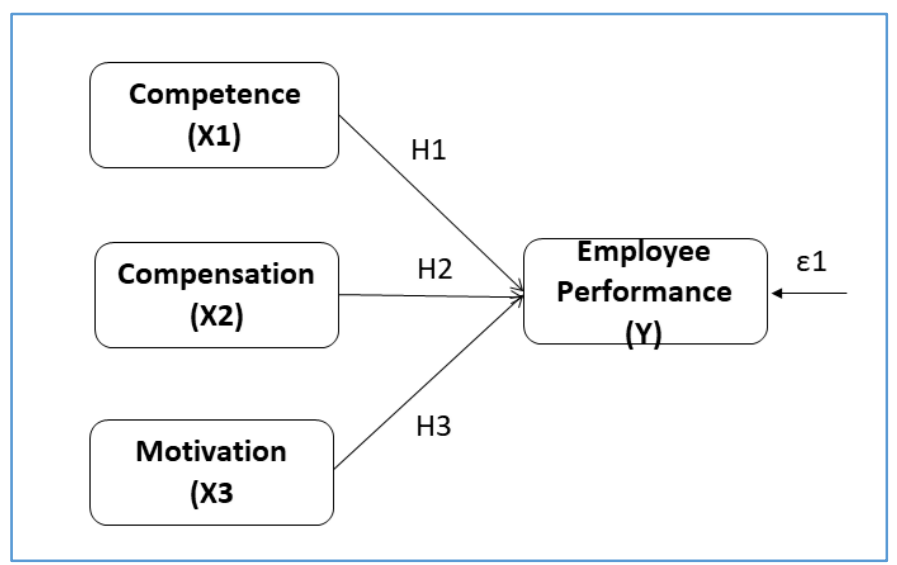

Picture 1: Conceptual frame work

Competence (X1), Compensation (X3) and Motivation (X3) affect employee performance (Y).

Apart from these three exogenous variables that affect employee performance (y), there are still many other variables that influence it, including:

1) Work Environment (x4): (Purba et al., 2017), (Sardjijo \& Ali, 2017);

2) Work Culture (x5): (Harini et al., 2020), (Elmi et al., 2016); dan

3) Job Performance (X6): (Riyanto, Sutrisno, et al., 2017a), (Thanh Nguyen et al., 2019), (Riyanto, Sutrisno, et al., 2017b), dan (Riyanto, Sutrisno, et al., 2017a). 


\section{CONCLUSIONS AND SUGGESTIONS}

\section{Conclusions}

Based on the above discussion, it can be concluded to build a hypothesis for further research.

1) Competence has a relationship and affects employee performance

2) Compensation has a relationship and affects employee performance

3) Motivation has a relationship and affects employee performance

Suggestions

There are still many other factors that can affect employee performance or employee performance at all types and levels of the organization, therefore further studies are needed to complement other factors that have not been mentioned in this article that can affect employee performance.

\section{BIBLIOGRAPHY}

Agussalim, M., Ayu Rezkiana Putri, M., \& Ali, H. (2016). Analysis work discipline and work spirit toward performance of employees (case study tax office Pratama two Padang). International Journal of Economic Research.

Agussalim, M., Kristin, M., \& Ali, H. (2016). Role of revolving loan program community national urban self (PNPM MP) against poverty prevention in Padang. International Journal of Applied Business and Economic Research.

Ali, H (2010). Sistem Informasi Bisnis "SI-Bis" Dalam Prosfektif Keunggulan Kompetitif. Jambi: www.hapzi.com.

Ali, H., Limakrisna, N., \& Jamaluddin, S. (2016). Model of customer satisfaction: The empirical study at Bri in Jambi. International Journal of Applied Business and Economic Research.

Amin, N. M. (2015). PENGARUH KOMPETENSI TERHADAP KINERJA PEGAWAI DI SEKRETARIAT DAERAH KABUPATEN SIDENRENG RAPPANG. Jurnal Ekonomi dan Manajemen Sistem Informasi, 1-7.

Ansori, A., \& Ali, H. (2017). Analisis Pengaruh Kompetensi Dan Promosi Terhadap Kinerja Pegawai Negeri Sipil Pada Sekretariat Daerah Kabupaten Bungo. Jurnal Ilmiah Universitas Batanghari Jambi. https://doi.org/10.33087/jiubj.v15i1.198

Bastari, A., -, H., \& Ali, H. (2020). DETERMINANT SERVICE PERFORMANCE THROUGH MOTIVATION ANALYSIS AND TRANSFORMATIONAL LEADERSHIP. International Journal of Psychosocial Rehabilitation. https://doi.org/10.37200/ijpr/v24i4/pr201108

Brata, Husani, Hapzi, B. H. S. A. (2017). Saudi Journal of Business and Management Studies Competitive Intelligence and Knowledge Management: An Analysis of the Literature. Saudi Journal of Business and Management Studies. https://doi.org/10.21276/sjbms

Chauhan, R., Ali, H., \& Munawar, N. A. (2019). BUILDING PERFORMANCE SERVICE THROUGH TRANSFORMATIONAL LEADERSHIP ANALYSIS, WORK STRESS AND WORK MOTIVATION (EMPIRICAL CASE STUDY IN STATIONERY 
DISTRIBUTOR COMPANIES). Dinasti International Journal of Education Management And Social Science. https://doi.org/10.31933/dijemss.v1i1.42

Cresswel, J. (1998). Qualitatif Inquiry and Research Design. California: Sage Publications, Inc.

Desfiandi, A., Desfiandi, A., \& Ali, H. (2017). Composite Stock Price Index (IHSG) Macro Factor in Investment in Stock (Equity Funds). International Journal of Economics and Financial Issues.

Djojo, A., \& Ali, H. (2012). Information technology service performance and client's relationship to increase banking image and its influence on deposits customer banks loyalty (A survey of Banking in Jambi). In Archives Des Sciences.

Djoko Setyo Widodo, P. Eddy Sanusi Silitonga, \& H. A. (2017). Organizational Performance: Analysis of Transformational Leadership Style and Organizational Learning. Saudi Journal of Humanities and Social Sciences. https://doi.org/10.21276/sjhss.2017.2.3.9

Dwianto, A. S. (2019). Pengaruh Kompensasi Terhadap Kinerja Karyawan Pada PT. JAEIL INDONESIA. Jurnal Ekonomi dan Ekonomi Syariah, 5-6.

Elmi, F., Setyadi, A., Regiana, L., \& Ali, H. (2016). Effect of leadership style, organizational culture and emotional intelligence to learning organization: On the Human Resources Development Agency of Law and Human Rights, Ministry of Law and Human Rights. International Journal of Economic Research.

Firmandari, N. (2014). Pengaruh Kompensasi Terhadap Kinerja Karyawan Dengan Motivasi Kerja Sebagai Variabel Moderasi. Jurnal Ekonomi dan Bisnis Islam, 25-27.

Harini, S., Hamidah, Luddin, M. R., \& Ali, H. (2020). Analysis supply chain management factors of lecturer's turnover phenomenon. International Journal of Supply Chain Management.

Prayetno, S., \& Ali, H. (2017). Analysis of advocates organizational commitment and advocates work motivation to advocates performance and its impact on performance advocates office. International Journal of Economic Research.

Prihartono, \& Ali, H. (2020). The promises ethics and marketing concept strategy as a competitive advantage on private higher education (A survey on perception of product attributes and promotion mix in Indonesia). Talent Development and Excellence.

Purba, C. B., Arzio, \& Ali, H. (2017). The influence of compensation, working environment and organization culture on working productivity of BPJS (workers social security agency) employment staff in Rawamangun Branch. Man in India.

Ridwan, M., Mulyani, S. R., \& Ali, H. (2020). Building behavior and performance citizenship: Perceived organizational support and competence (case study at SPMI private university in west Sumatra). International Journal of Psychosocial Rehabilitation. https://doi.org/10.37200/IJPR/V24I6/PR260195

Rivai, A., Suharto, \& Ali, H. (2017). Organizational performance analysis: Loyalty predictors are mediated by work motivation at urban village in Bekasi City. International Journal of Economic Research. 
Riyanto, S., Pratomo, A., \& Ali, H. (2017). EFFECT OF COMPENSATION AND JOB INSECURITY ON EMPLOYEE ENGAGEMENT (STUDY ON EMPLOYEE OF BUSINESS COMPETITION SUPERVISORY COMMISSION SECRETARIAT). International Journal of Advanced Research. https://doi.org/10.21474/ijar01/4139

Riyanto, S., Sutrisno, A., \& Ali, H. (2017a). International Review of Management and Marketing The Impact of Working Motivation and Working Environment on Employees Performance in Indonesia Stock Exchange. International Review of Management and Marketing.

Riyanto, S., Sutrisno, A., \& Ali, H. (2017b). The Impact of Working Motivation and Working Environment on Employees Performance in Indonesia Stock Exchange. International Review of Management and Marketing.

Rangga Mahardhika, D. H. (2013). PENGARUH MOTIVASI KERJA TERHADAP KINERJA KARYAWAN. Jurnal Administrasi Bisnis, 1-4.

Ridwan Isya Luthfi, H. S. (2014). PENGARUH MOTIVASI TERHADAP KINERJA KARYAWAN. Jurnal Ekonomi dan Manajemen Sistem Informasi, 2-3.

Sofyandi, H. (2008). Manajemen Sumber Daya Manusia, Edisi Pertama. Yogyakarta: Graha Ilmu.

Stephen P. Robbins, T. A. (2008). Perilaku Organisasi. Jakarta: Salemba Empat.

Sardjijo, S., \& Ali, H. (2017). Integrating Character Building into Mathematics and Science Courses in Elementary School. International Journal of Environmental and Science Education. https://doi.org/10.1007/s10648-016-9383-1

Sulaeman, A. S., Waluyo, B., \& Ali, H. (2019). Making dual procurement and supply chain operations: Cases in the indonesian higher education. International Journal of Supply Chain Management.

Thanh Nguyen, P., Ali, H., \& Agung Hudaya. (2019). MODEL BUYING DECISION AND REPEAT PURCHASE: PRODUCT QUALITY ANALYSIS (Case Study of Bank Permata Syariah Jakarta KPR Financing Customers). Dinasti International Journal of Management Science. https://doi.org/10.31933/dijms.v1i1.29 